\title{
Impacts of the Sustainable Forestry Initiative Landscape Level Measures on Hydrological Processes
}

\author{
JOÃO C. AZEVEDO ${ }^{1, *}$, JIMMY R. WILLIAMS ${ }^{2}$, MICHAEL G. MESSINA ${ }^{3}$ \\ and RICHARD F. FISHER ${ }^{4}$ \\ ${ }^{1}$ Departamento Florestal, Escola Superior Agrária, Instituto Politécnico de Bragança, Campus de \\ Santa Apolónia-Apartado 172, 5301-854 Bragança, Portugal; ${ }^{2}$ Blackland Agricultural Research \\ Center, Texas A\&M University, 808 E, Blackland Road, Temple, TX 76502, U.S.A.; ${ }^{3}$ Department of \\ Forest Science, Texas A\&M University, College Station, TX 77843-2135, U.S.A.; ${ }^{4}$ Temple-Inland, \\ P.O. Drawer N or 303 S. Temple Dr., Diboll, TX 75941, U.S.A. \\ (*author for correspondence, e-mail: jazevedo@ipb.pt; Fax:+351-273325405)
}

(Received: 21 November 2003; in final form: 27 May 2004)

\begin{abstract}
The effects on hydrological processes of the application of the landscape level measures included in the sustainable forestry initiative (SFI) program were analyzed through simulation. A landscape scenario where limitation of harvesting units' size, imposition of a green-up interval, and establishment of streamside management zones (SMZ) were simulated was compared with a reference scenario where no SFI rules were followed. An intensively managed forested landscape located in East Texas, USA, was used as the study area. The HARVEST landscape model was used to simulate landscape pattern and a modified version of the APEX model was used to simulate hydrological processes. Water and sediment yields were generally small within the observation period and most of the runoff and erosion observed occurred during intense storm events. Water and sediment yield at the subarea level and water yield at the watershed level were similar in both scenarios. However, sediment yield at the watershed level was higher in the non-SFI scenario. The differences were due to the reduction in channel erosion resulting from the presence of SMZs. The effect of buffer zones in terms of sediment deposition was not different between scenarios, which can be attributed to the level slopes of the study area. Landscape measures of the SFI program, namely buffer zones, seem important in reducing channel degradation, particularly during major storm events, in intensively managed forest landscapes in East Texas.
\end{abstract}

Key words: APEX model, East Texas, hydrological modeling, sediment yield, sustainable forest initiative, sustainable forestry, water yield

\section{Introduction}

Forest activities affect soil loss and water quality and supply by interfering with physical, chemical, and biological processes at the site and watershed scales. In the southern region of the US, harvesting and site preparation methods used in intensive silviculture of pine species can increase stormflow and sediment loss (Beasley et al., 1986; Marion and Ursic, 1993). The removal of forest biomass by harvesting reduces interception and transpiration by forest canopies, increasing potential 
runoff (Chang et al., 1982; Ursic, 1991a). Harvesting alone does not increase sediment concentration (Ursic, 1986; McClurkin et al., 1987), but compaction and soil exposure during extraction can affect runoff and sediment yield through changes in soil structure.

Sediment yield is usually related to the proportion of exposed mineral soil (Ursic, 1986; Blackburn et al., 1986), which increases potential degradation and transport, by erosion agents. For this reason, site preparation has in many cases a strong effect on water yield and sediment loss, though its effects are variable according to the techniques used (Beasley and Granillo, 1983; Ursic, 1986; Blackburn et al., 1990).

All the effects mentioned usually have a short-term effect (Beasley and Granillo, 1988; Marion and Ursic, 1993). The major and more permanent source of erosion in forests is forest roads, which can account for up to $90 \%$ of all the sediment produced in forestlands (Grace, 2002).

Environmental concerns have led to the implementation of measures to minimize impacts of forestry activities on water. After the enactment of the Federal Water Pollution Control Act Amendments of 1972, 1977 and 1987, States of the US developed enforceable or voluntary best management practices (BMP) programs to be applied in forestry (Ice et al., 1997). More recently, forestry sustainability programs assumed water and soil conservation as essential criteria of sustainable forestry (e.g. Montréal Process Working Group, 1999; Ministerial Conference on the Protection of Forests in Europe, 2003).

Since 1994, the forest products industry in the US has largely followed the sustainable forestry initiative (SFI), the sustainability program of the American Forest and Paper Association (AF\&PA, 2003). The SFI program includes measures relevant at the landscape level, such as limitations on size of harvest units, establishment of wildlife corridors, establishment of streamside management zones (SMZs), and application of adjacency rules. In East Texas, landscape pattern in intensively managed forests is being changed by the implementation of the SFI program (Azevedo et al., 2003). These changes can be summarized as an increase in buffer zones that follow a stream configuration and as an increase in the fragmentation of upland pine stands resulting from the intrusion of SMZs and from the constraints imposed by the green-up interval and limits on harvest unit size (see Azevedo et al. (2003) for details).

The aim of this work is to analyze the effects of the SFI program on the hydrology of forested watersheds. The specific objective is to analyze the effects of changes in landscape pattern as influenced by the SFI program on water and sediment yield in an intensively managed forested watershed in East Texas. It is hypothesized that changes in landscape structure have implications in terms of hydrological processes in the watershed. SMZs have been shown to affect water and sediment transport and yield after harvesting and site preparation (Wynn et al., 2000). Fragmentation creates heterogeneity in the landscape decreasing the percentage of watershed or catchment area harvested annually, thus potentially reducing extreme water and sediment yields. 


\section{Methodology}

\subsection{STUDY AREA}

This study was conducted in a portion of the Shawanee Creek watershed (Neches River) located in Angelina County, Texas, USA (Figure 1). This area has been studied in terms of landscape pattern change resulting from the application of the SFI program and resulting consequences in terms of vertebrates' habitat suitability (Azevedo et al., 2003). From this larger area, an 1190 ha watershed was chosen for the analysis of hydrological processes.

The study area lays in the Yegua Formation of coastal plain sediments of late Eocene origin. This formation is made up of sandstones and mudstones with inclusions of lignite and glauconitic marl. The gradient is less than $0.20 \mathrm{~m}$ per $\mathrm{km}$ to the southeast. Soils are mainly Alfisols of the Diboll and Alazan series and Ultisols of the Rosenwall series (Table I). Slopes are usually gentle, $2 \%$ on average with a maximum of $7 \%$. The drainage system is mature with widely meandering streams. The network of current and ancient stream channels is complex due to the influence of changing sea level during the Pleistocene. Actual cover is almost exclusively comprises loblolly pine (Pinus taeda L.) plantations with few hardwood and pine-hardwood mixed stands.

\subsection{THE APEX MODEL}

The Agriculture Policy/Environment eXtender (APEX) model (Williams et al., 2000), version 1310, was used in this work to model and simulate the hydrology of forested watersheds and to analyze the effects of landscape pattern on hydrological processes, namely runoff and erosion.

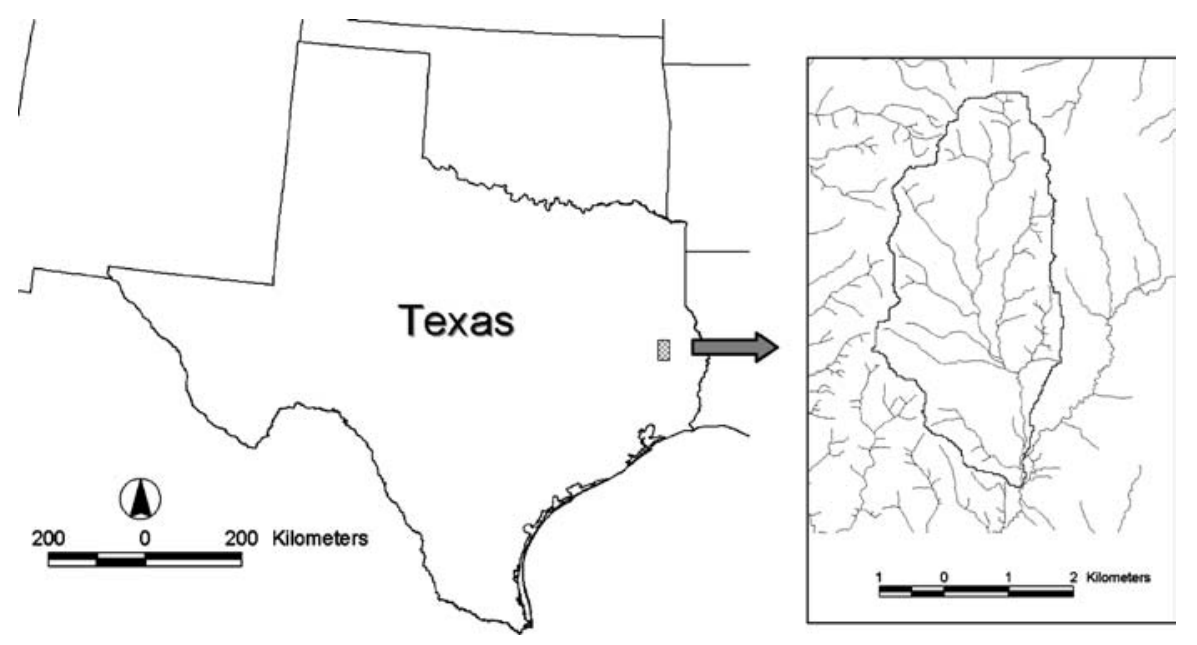

Figure 1. Location of the study area. 
Table I. Soil series distribution in the study area

\begin{tabular}{lrr}
\hline & \multicolumn{2}{c}{ Area } \\
\cline { 2 - 3 } Soil series & \multicolumn{1}{c}{ (ha) } & $(\%)$ \\
\hline DIBOLL & 493.8 & 41.5 \\
ALAZAN & 229.2 & 19.3 \\
ROSENWALL & 206.3 & 17.3 \\
KELTYS & 93.7 & 7.9 \\
RAYLAKE & 71.3 & 6.0 \\
HERTY & 60.9 & 5.1 \\
KOURY & 14.1 & 1.2 \\
MOSWELL & 10.3 & 0.9 \\
KURTH & 9.8 & 0.8 \\
\hline
\end{tabular}

APEX is a mechanistic model that combines the Environmental Policy Integrated Climate (EPIC) model (Williams, 1995) with routing capabilities allowing the analysis of processes occurring simultaneously at the field and watershed levels. The main purpose of APEX is to estimate long-term sediment, nutrient, and pesticide yields from whole farms and small watersheds (Williams et al., 2000).

EPIC was initially developed to determine the relationship between soil erosion and productivity (Williams et al., 1984). Its growing capabilities made it a powerful tool in the analysis of the effects of management strategies on production and soil and water resources at the field scale (Williams, 1995). The model currently includes a series of components to simulate soil, plant, weather, and management processes at the field scale (Williams, 1990). It has been used widely in diverse applications in the US and other countries (Williams, 1995; Williams et al., 1998).

EPIC assumes the land unit to be spatially homogeneous (Williams et al., 1984). APEX extends the scale of the model from the field to the whole farm or small watershed scale by allowing heterogeneity of fields and their spatial arrangement to be taken into account and by integrating routing components for water, sediment, nutrients, and pesticides (Williams et al., 2000). These routing components are able to simulate landscape processes such as sediment transport, deposition, channel degradation, and lateral subsurface flow (Williams et al., 1998).

Although APEX was developed to compare management alternatives in agriculture, it has recently been modified to describe hydrological processes in forested areas (Saleh et al., 2002). Modifications were made in the canopy interception, litter, subsurface flow, and nutrient movement and enrichment ratio components (Saleh et al., 2002). Additionally, APEX is able to account for the effects of buffer strips on water and sediment (Saleh et al., 2002), which is of great relevance in forestry since buffers along streams are one of the major measures in sustainability programs. A detailed description of the model components dealing with forest conditions is presented in Saleh et al. (2002). 
Surface runoff was obtained for daily rainfall from the soil conservation service (currently Natural Resources Conservation Service) curve number equation (U.S. Department of Agriculture, Soil Conservation Service, 1972):

$$
\begin{aligned}
& Q=\frac{(R-0.2 s)^{2}}{R+0.8 s}, \quad R>0.2 s \\
& Q=0.0, \quad R \leq 0.2 s
\end{aligned}
$$

where $Q$ is the daily runoff, $R$ is the daily rainfall, and $s$ is a retention parameter. This parameter changes with fluctuations in soil water content according to the equation

$$
s=s_{1}\left(1-\frac{F F C}{F F C+\exp \left[w_{1}-w_{2}(F F C)\right]}\right)
$$

where $s_{1}$ is the value of $\mathrm{s}$ associated with $\mathrm{CN}_{1}$, the curve number for moisture condition 1 (dry), FFC is the fraction of field capacity, and $w_{1}$ and $w_{2}$ are shape parameters.

Peak runoff rate was estimated from the rational equation method:

$$
q_{p}=\frac{b Q \cdot r \cdot W S A}{360}
$$

where $q_{p}$ is the peak runoff rate in $\mathrm{m}^{3} \mathrm{~s}^{-1}, b Q$ is a runoff coefficient expressing the watershed infiltration characteristics, $r$ is the rainfall intensity in $\mathrm{mm} \mathrm{h}^{-1}$ for the watershed's time of concentration, and WSA is the watershed area in hectare.

Percolation was computed as

$$
O_{l}=\left(S T_{l}-F C_{l}\right) \cdot\left(1.0-\exp \left(\frac{-24}{T T_{l}}\right)\right)
$$

where $O$ is the percolation rate for layer $l$ in $\mathrm{mm} \mathrm{d}^{-1}, S T$ and $F C$ are soil water content and field capacity, respectively, in $\mathrm{mm}$ and $T T$ is travel time through layer $l$ in $\mathrm{h}$.

Potential evapotranspiration was predicted from the Hargreaves method (Hargreaves and Samani, 1985) by modifying the temperature difference exponent from 0.5 to 0.6 , replacing the extraterrestrial radiation by RAMX (maximum possible solar radiation at the earth's surface) and adjusting the coefficient from 0.0023 to 0.0032 for proper conversion

$$
E o=0.0032 \cdot\left(\frac{R A M X}{H V}\right)(T+17.8)\left(T_{\max }-T_{\min }\right)^{0.6}
$$


where $E o$ is the potential evaporation in $\mathrm{mm}, T, T_{\max }$, and $T_{\min }$ are the daily mean, maximum, and minimum air temperature, respectively, in ${ }^{\circ} \mathrm{C}$, and $H V$ is the latent heat of vaporization in $\mathrm{MJ} \mathrm{kg}^{-1}$.

Rainfall/runoff erosion was simulated with MUSLE (Williams, 1975), a model that uses only runoff variables to simulate erosion and sediment yield which increase the prediction accuracy, eliminate the need for the delivery ratio used in the USLE equation, and enable the equation to give single storm estimates of sediment yields. The equation is

$$
\begin{aligned}
& Y=\chi(K)(C E)(P E)(L S)(R O K F) \\
& \chi=1.586\left(Q \cdot q_{p}\right)^{0.56} W S A^{0.12}
\end{aligned}
$$

where $Y$ is the sediment yield in $\mathrm{t} \mathrm{ha}^{-1}, K$ is the soil erodibility factor, $C E$ is the crop management factor, $P E$ is the erosion control practice factor, $L S$ is the slope length and steepness factor, $R O K F$ is the coarse fragment factor.

APEX estimates the average flow velocity for the channel and floodplain separately considering average daily flow rate and the hydraulic characteristics of the channel and floodplain. Also, sediment routing is performed for the channel and floodplain separately. The sediment routing equation was based upon Bagnold's sediment transport equation (Bagnold, 1977):

$$
C Y U=C Y 1 \cdot V C H^{P_{18}}
$$

where $C Y U$ is the potential sediment concentration in $\mathrm{t} \mathrm{m}^{-3}$ for the flow velocity $V C H, C Y 1$ is the potential sediment concentration for velocity $1.0 \mathrm{~m} \mathrm{~s}^{-1}$, and $P_{18}$ is a parameter set at 1.5 in Bagnold's equation.

The potential change in sediment yield through a routing reach is calculated as the difference between inflow and potential concentration

$$
Y U=10 . \cdot Q C H \cdot(C Y U-C I N)
$$

where $Y U$ is the potential change in sediment yield in $\mathrm{tha}^{-1}, Q C H$ is the volume of flow through the channel in $\mathrm{mm}, C Y U$ is the potential sediment concentration in

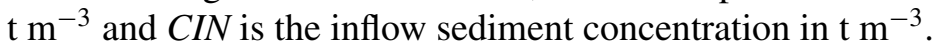

\subsection{LANDSCAPE SIMULATION}

The dynamics of landscape structure were simulated with HARVEST 6.0 (Gustafson and Crow, 1999). One scenario (SFI scenario) was established based upon the application of SFI landscape measures, namely SMZs $\geq 30 \mathrm{~m}$ wide along perennial and intermittent streams, a 49 ha limit in harvest unit size in pine stands, and a three-year green-up interval. SMZs are stream buffer zones locally managed 
to maintain a minimum basal area of $11.5 \mathrm{~m}^{2} / \mathrm{ha}$ as required by the best management practices in Texas (Texas Forest Service, 2000). For comparison purposes a reference scenario (non-SFI scenario) was established in the absence of these rules.

\subsection{WATERSHED DISCRETIZATION}

The watershed delineation module of SWAT2000, ArcView interface (Di Luzio et al., 2002) was used in the delineation of subareas based upon $30 \mathrm{~m}$ resolution digital elevation model (DEM) data (United States Geological Survey). The minimum size of sub-basins chosen was 14 ha. The larger sub-basins created in spite of this constraint were manually subdivided to reduce soil and stand variability within subareas and to minimize the effect of the measurement of channel length that occurs in subareas larger than 20 ha in size. GIS coverages created in the process of delineation provide part of the data to be used in the preparation of the subareas files.

In each sub-basin additional discretization was done to account for the presence of different forest stands and for buffer zones. Each of these units constitutes a subarea for modeling purposes. Subareas smaller than 2 ha were excluded, unless they were buffer strips.

For each of the scenarios routing was schematized in a diagram based upon SWAT sub-basin coverages and stand maps derived from HARVEST (Figure 2).

SFI

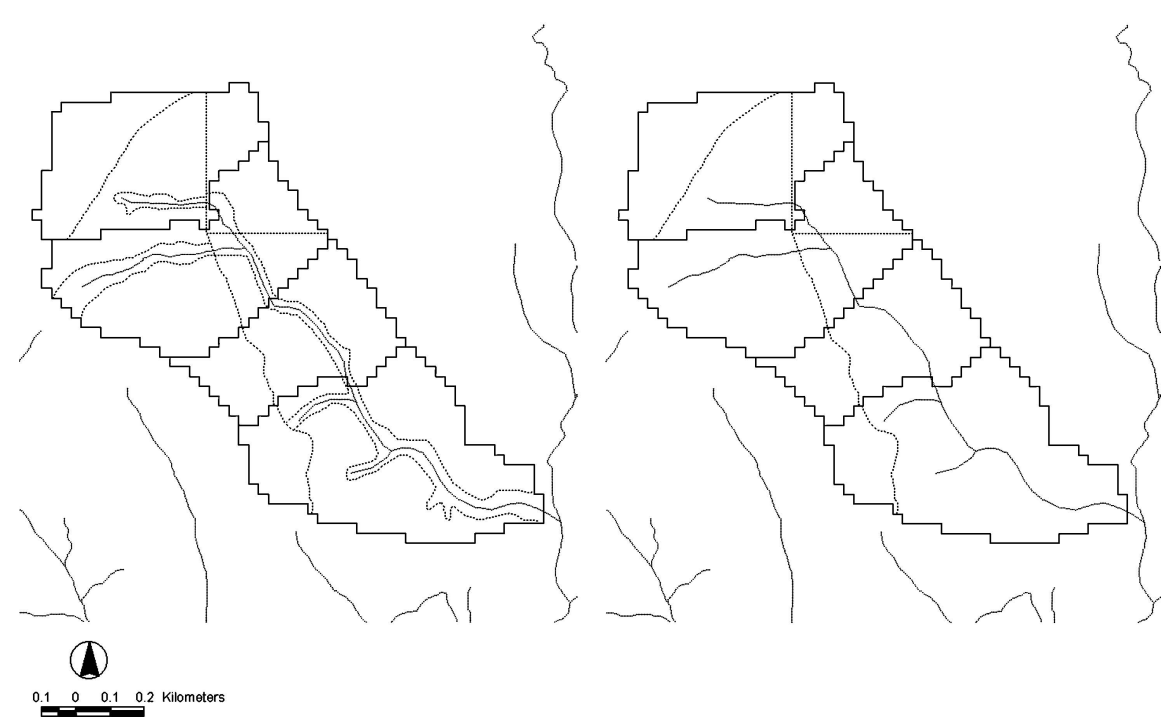

Figure 2. Detail of subareas in an 80-ha watershed within the study area for SFI and Non-SFI scenarios. Sub-basins defined based upon elevation data (solid lines) were further subdivided considering forest stands and SMZs (dashed lines). 
Each entering subarea was quantified in terms of area (ha), channel length (km), channel slope $(\mathrm{m} / \mathrm{m})$, reach channel length $(\mathrm{km})$, reach channel slope (when present) $(\mathrm{m} / \mathrm{m})$, average upland slope $(\mathrm{m} / \mathrm{m})$, and upland slope length $(\mathrm{m})$. Receiving subarea, operation schedule file, and soil file were also associated to each entering subarea. Soil series distribution in the study area was obtained from a SSURGO digital map for Angelina County (Soil Survey Geographic Data Base, USDANatural Resources Conservation Service).

\subsection{OPERATION SCHEDULES}

Each stand was managed by particular operation schedules according to composition and age. Operation schedule files intended to describe as accurately as possible the stand development along time and the management operations followed in the stands. At the same time these files allow the synchronization of dynamics simulated in APEX with stand and landscape dynamics simulated in HARVEST.

In this study four possible management types were followed: pine-clearcutting, pine-selection, hardwood-selection, and pine-hardwood-selection (Azevedo et al., 2003). For pine-clearcutting, plantation and harvesting year for each stand were defined according to the sequence of clearcuttings in the landscape dynamics component (HARVEST). Since the rotation time was $30 \mathrm{yr}$ and the landscape dynamics model works on a two-year time step, 15 different operation schedule management plans were defined, one for each possible year of harvesting/planting. These files include planting of 950 trees/ha, thinning to 450 trees/ha at age 15 , and harvesting at age 30. An offset disk operation was used to simulate perturbation due to site preparation. Harvesting occurs in April, offset disk operation in October, and planting in December of the same year.

Hardwood stands are represented by sweetgum and mixed pine-hardwood stands are represented by a mixture of pine and sweetgum. These stands were considered not managed in terms of APEX and were maintained at a constant density of 450 trees/ha during the period of simulations.

\subsection{EVALUATION OF THE MODEL}

In the absence of sediment and water yield data for the study area, the model could not go through a validation process as is usually performed in this kind of approach. Since the main purpose of APEX is to compare management scenarios, it was considered acceptable to use the model without such validation and eventual calibration. Parameterization of the model for forest conditions in East Texas has been done in Saleh et al. (2002). Evaluation of the model for the study area was done in controlled subareas by submitting the model to different magnitudes and combinations of parameter values including soil series, crop type, initial density, thinning intensity, age to maturity, partition flow through filter strips, and slope, among others. Different subarea delineations were also analyzed to evaluate the role of discretization on the processes simulated including the effect of buffer strips 
on runoff and sediment loss. Key parameters used as indicators of the model performance include runoff, sediment yield, percolation, deposition, degradation, crop biomass, leaf area index (LAI), and evapotranspiration. Published data from Pope and Graney (1979), Hebert and Jack (1997), Baldwin et al. (2000), and Gresham and Williams (2002) for biomass and LAI, and several works on sediment and runoff in forested catchments in East Texas (e.g. Yoho, 1980; Ursic, 1986; Blackburn et al., 1990) were used in the evaluation of the model.

\subsection{SIMULATIONS}

Three simulations for each scenario (SFI and non-SFI) were performed using different IGN (number of times random number generator cycles before simulations) to create variability of weather conditions. Results were obtained for a period of $30 \mathrm{yr}$ corresponding to a cycle in the landscape dynamics of the study area. Simulations were started $30 \mathrm{yr}$ before the $30 \mathrm{yr}$ period of interest to allow crop growth and stabilization of the system. Weather data were generated by APEX based upon parameters for Lufkin, Texas.

\section{Results and Discussion}

Runoff, water yield, and sediment loss observed during the simulations (Table II) were generally small. These values were within the range of values observed in forested watersheds in East Texas and other areas in the South (Yoho, 1980; Blackburn et al., 1986; Ursic, 1986; Ursic, 1991b). Runoff and sediment yield here were higher than measured values in non-disturbed pine watersheds which should be

Table II. Average annual precipitation, runoff and water and sediment yield in three APEX simulations for the study watershed. QSS-average subarea surface runoff; QSW-average watershed surface runoff; QTS-average subarea water yield; QTW-average watershed water yield; YS-average subarea sediment yield; YW-average watershed sediment yield

\begin{tabular}{llllllll}
\hline Simulation & $\begin{array}{l}\text { Precipitation } \\
(\mathrm{mm})\end{array}$ & $\begin{array}{l}\text { QSS } \\
(\mathrm{mm})\end{array}$ & $\begin{array}{l}\text { QSW } \\
(\mathrm{mm})\end{array}$ & $\begin{array}{l}\text { QTS } \\
(\mathrm{mm})\end{array}$ & $\begin{array}{l}\text { QTW } \\
(\mathrm{mm})\end{array}$ & $\begin{array}{l}\text { YS } \\
(\mathrm{t} / \mathrm{ha})\end{array}$ & $\begin{array}{l}\text { YW } \\
(\mathrm{t} / \mathrm{ha})\end{array}$ \\
\hline SFI & & & & & & & \\
$\quad 1$ & 1093.9 & 23.15 & 22.75 & 30.51 & 30.03 & 0.09 & 0.17 \\
2 & 1056.0 & 17.97 & 17.62 & 23.21 & 22.78 & 0.08 & 0.16 \\
3 & 1074.2 & 20.81 & 20.43 & 27.21 & 26.74 & 0.09 & 0.16 \\
Average & 1074.7 & 20.64 & 20.27 & 26.98 & 26.52 & 0.09 & 0.16 \\
& & & & & & & \\
Non-SFI & & & & & & & \\
1 & 1093.9 & 23.10 & 22.90 & 30.27 & 30.00 & 0.09 & 0.42 \\
2 & 1056.0 & 17.84 & 17.67 & 23.11 & 22.87 & 0.07 & 0.34 \\
3 & 1074.2 & 20.80 & 20.62 & 27.15 & 26.89 & 0.09 & 0.38 \\
Average & 1074.7 & 20.58 & 20.40 & 26.84 & 26.59 & 0.08 & 0.38 \\
\hline
\end{tabular}


Table III. Area, average slope, surface runoff, and sediment yield per forest type in the SFI scenario. QS-average subarea surface runoff; YS-average subarea sediment yield

\begin{tabular}{|c|c|c|c|c|c|c|c|c|c|c|}
\hline & \multirow{2}{*}{$\begin{array}{l}\text { Area } \\
(\%)\end{array}$} & \multirow{2}{*}{$\begin{array}{l}\text { Slope } \\
(\%)\end{array}$} & \multicolumn{4}{|c|}{ QS (mm) } & \multicolumn{4}{|c|}{ YS (t/ha) } \\
\hline & & & Run 1 & Run 2 & Run 3 & Average & Run 1 & Run 2 & Run 3 & Average \\
\hline Pine-clearcut & 75.4 & 2.2 & 23.23 & 18.00 & 20.90 & 20.71 & 0.08 & 0.06 & 0.08 & 0.07 \\
\hline Hardwood & 10.8 & 1.2 & 17.50 & 13.78 & 15.89 & 15.72 & 0.03 & 0.03 & 0.03 & 0.03 \\
\hline Pine-selection & 0.6 & 1.8 & 29.98 & 23.00 & 26.42 & 26.47 & 2.98 & 2.88 & 2.90 & 2.92 \\
\hline Pine-hardwood & 13.2 & 1.5 & 26.99 & 20.97 & 24.10 & 24.02 & 0.05 & 0.05 & 0.04 & 0.05 \\
\hline
\end{tabular}

expected since harvesting and site preparation were part of the management of the simulated pine stands. These values were lower than published results for many managed stands which is also to be expected, since measurements in the literature refer to fewer years after the application of forest practices than our simulated period of $30 \mathrm{yr}$. Other reasons that might explain these differences are the lower annual mean precipitation and nearly level slopes in the study area.

SFI and non-SFI management produced the same amount of surface runoff and water yield at the subarea and watershed levels (Table II). In the SFI scenario, runoff and sediment loss were lower in the buffer strips comprising hardwoods than in the upper areas comprising pine under the clearcutting system (Table III). Slope is the major factor explaining these differences. Two stands with continuous pine cover showed the highest average runoff and sediment. This is due to lower tree density and biomass in these stands reducing evapotranspiration and increasing runoff and sediment yield. These variables should be similar to undisturbed pine stands (Beasley and Granillo, 1988). The non-SFI scenario mainly comprises pine stands managed by the clearcutting system.

Sediment yield at the subarea level was approximately the same in both scenarios (Table II). The non-SFI scenario showed, however, considerably more sediment yield at the watershed level than the SFI scenario. The difference in watershed sediment yield results from the routing processes, mainly channel degradation. Sediment deposition occurs as well, but it is very similar between landscape scenarios.

The weight of the sediment retained by this process in the overall area of study is discrete even in the scenario presenting buffer strips. On average, deposition was around $0.01 \mathrm{t} / \mathrm{ha}$ at the watershed level. Maximum average deposition in a route was $0.2 \mathrm{t} / \mathrm{ha}$. In the non-SFI scenario buffers were used only in particular cases, when this type of discretization better fit the arrangement of forest stands in the watershed, which explains in part the similarities in deposition between watersheds. The main reason for the small differences in deposition observed, however, is the fact that sediment loss is usually very low due to the nearly level slopes in the area. Deposition was visible only during intense storm events when sediment yield was high. This indicates that buffers even in areas of gentle slopes might be important in reducing non-point source pollution during periods of intense precipitation, which though infrequent occurred within the $30 \mathrm{yr}$ period of simulations. Buffer zones are 
able to retain considerable amounts of sediment produced by forest activities and are recommended measures to maintain water quality in managed forested areas (Wynn et al., 2000; Carling et al., 2001)

Channel degradation was common in both scenarios. It was, however, higher in the non-SFI scenario reaching annual average values of approximately $0.3 \mathrm{t} / \mathrm{ha}$ against $0.08 \mathrm{t} / \mathrm{ha}$ in the SFI scenario. Channel degradation was responsible for the differences in watershed sediment yield between the two landscapes. Channel degradation occurred to a greater extent in the non-SFI scenario that presents fewer buffer zones and also less fragmentation than the SFI landscape. As with deposition, degradation occured mostly in periods of intense precipitation. Channel degradation is often referred to in the literature as a major cause of erosion in forested watersheds (Ursic, 1986; Ursic, 1991b; Marion and Ursic, 1993). Studies on erosion often use small catchments to avoid channel erosion and account for forestland erosion only (Ursic, 1986).

Within the $30 \mathrm{yr}$ period of simulations, water and sediment yield were very irregular and average annual precipitation seemed not to have a very strong relation with annual yields (Figures 3 and 4). Monthly precipitation was more closely related to yields though it could not entirely explain differences between months (Figure 5). Daily precipitation had a strong influence on both annual and monthly results. Maximum precipitation values per simulation were more frequent in February and November. However, high daily precipitation values in February were usually responsible for higher runoff and erosion, which represented up to 90 and $95 \%$ of yearly runoff and sediment loss, respectively. Conversely, precipitation in November corresponded with low runoff and sediment yield. High values in February were probably due to the higher frequency of previous rain days that kept soil moisture high and caused the soil to reach saturation more quickly, increasing runoff and consequently erosion. Blackburn et al. (1986) also observed that intense storms in East Texas had a very high weight in annual water and sediment yields.

The effects of harvesting and site preparation on hydrological processes are not easily observed in the results (Figures 3-5). The fact that stands are continuously being harvested in the watershed combined with the irregularity in the distribution of precipitation, soil moisture, plant biomass growth, and the nearly level slope, makes these effects unclear in the results. Water and sediment yields increase considerably in the second and third years following major harvestings (Figure 6). These periods coincide, however, with years of either high annual or very high daily precipitation values, and whether this pattern is due to rainfall or harvestings is unclear. Possibly both factors play a role in the processes. Concentration of precipitation and exposed soils after harvesting and site preparation cause runoff and erosion to increase considerably even in nearly level terrain. The role of each factor is, however, unknown.

The results of this study synthesize a series of processes and their interactions occurring simultaneously at the stand and landscape levels. The fact that the watershed comprises many stands in many growth stages, soil conditions, and positions 


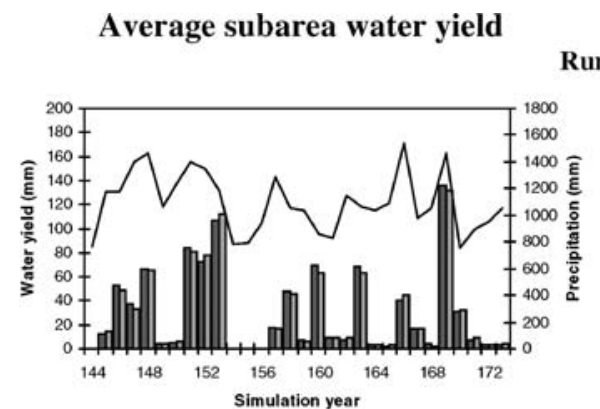

\section{Average subarea sediment yield}

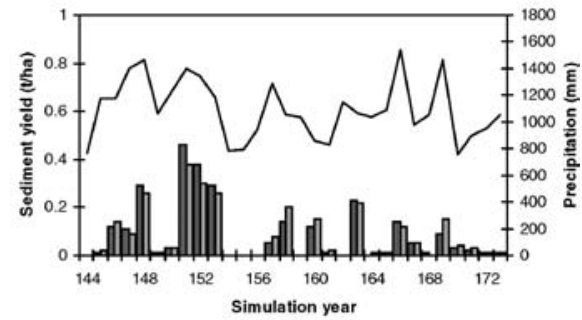

Run 2
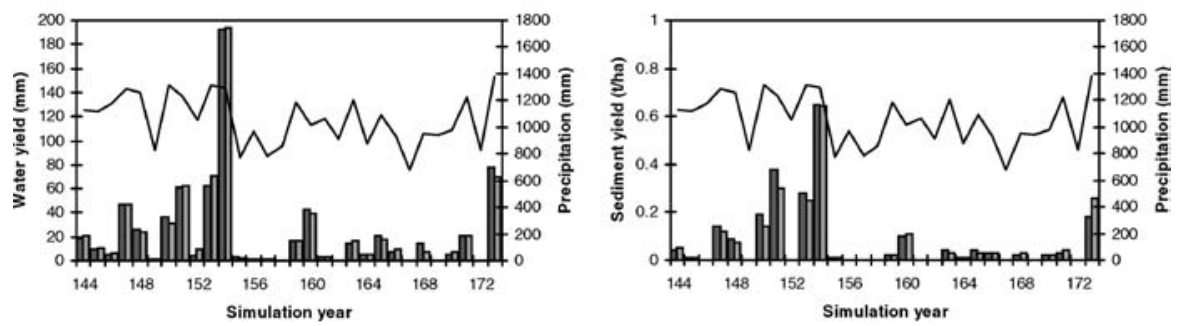

Run 3
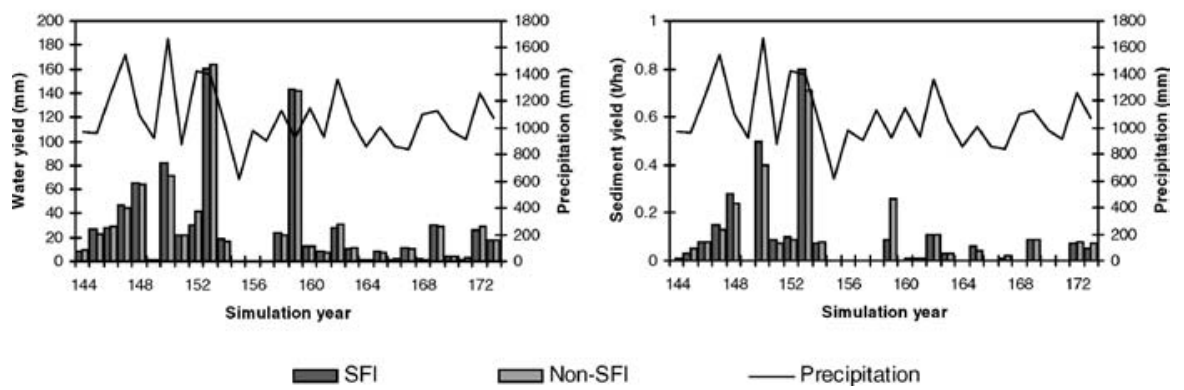

Figure 3. Average annual subarea water and sediment yield over the $30-\mathrm{yr}$ period of observations.

in the watershed combined with irregular weather conditions make the results difficult to interpret. Although subarea processes can be compared with published data, the overall results cannot since there appears to be no previous work done under similar conditions.

\section{Summary}

The results obtained at the subarea level were generally within the expected values for forested watersheds in East Texas under similar conditions. Water and sediment yields were generally small in the study area and most of the runoff and erosion observed occurred during intense storm events. Although water and sediment yield at the subarea scale and water yield at the landscape scale were similar between 

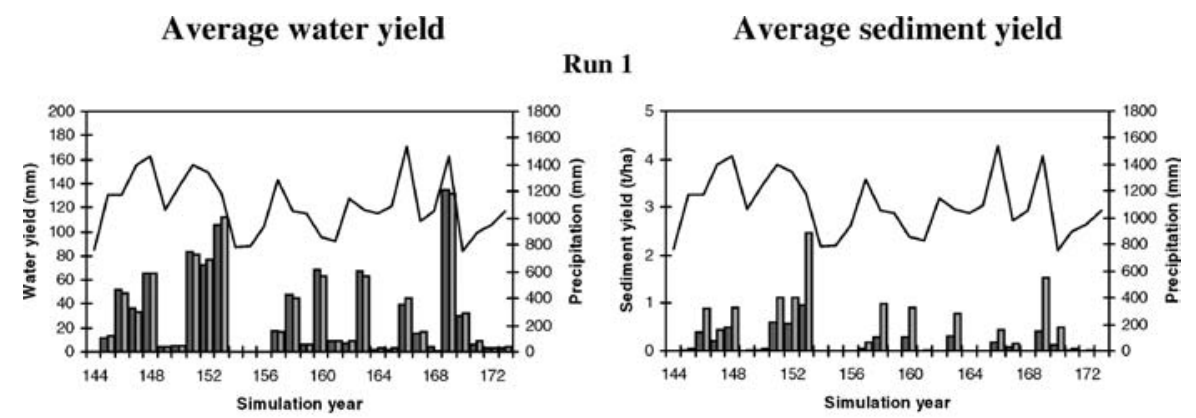

Run 2
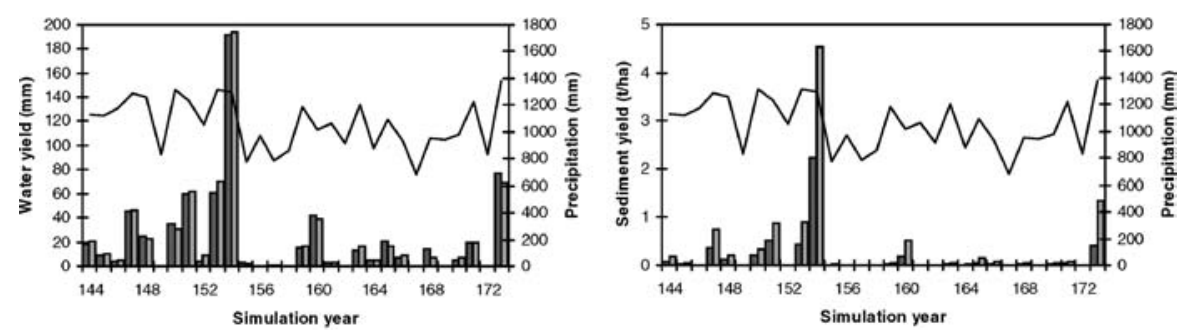

Run 3

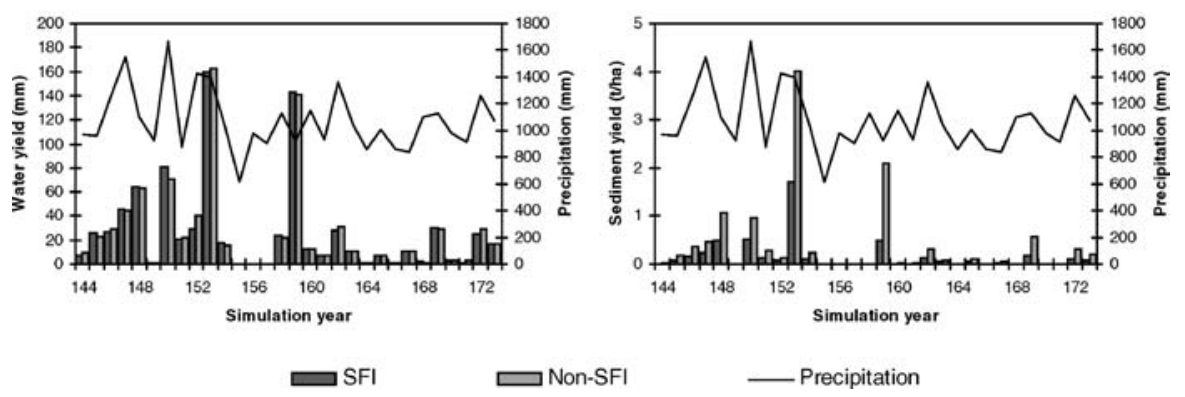

Figure 4. Average annual watershed water and sediment yield over the 30-yr period of observations.

scenarios, the non-SFI scenario had higher watershed sediment yield than the SFI scenario due to higher channel erosion. Measures implemented in the context of the SFI program seem to considerably reduce sediment loss mainly due to their effect on the reduction in channel erosion. This is particularly important during major storm events. The effect of buffer zones in terms of sediment deposition did not differ between scenarios probably because of the level slopes in the study area.

Recent developments in APEX made the model suitable for the analysis of the effects of management on forest hydrology. Further application of the model at that scale in East Texas can contribute positively to the evaluation of sustainability of forests in this and other regions. 


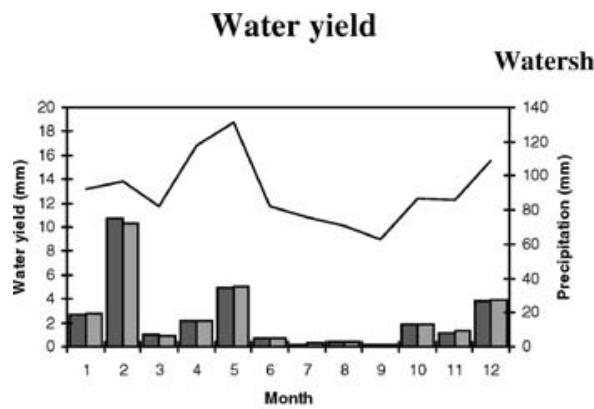

Subarea level

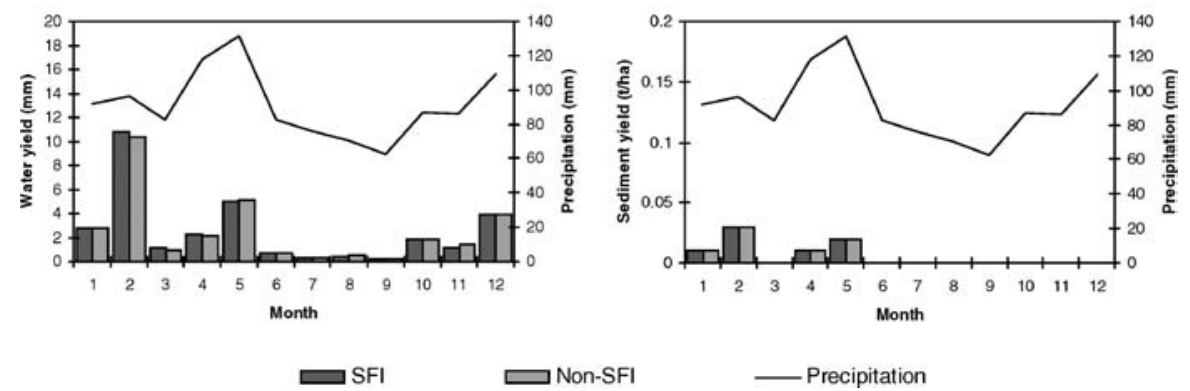

Figure 5. Average monthly watershed and subarea water and sediment yield for the $30-\mathrm{yr}$ period of observations for simulation 1 .

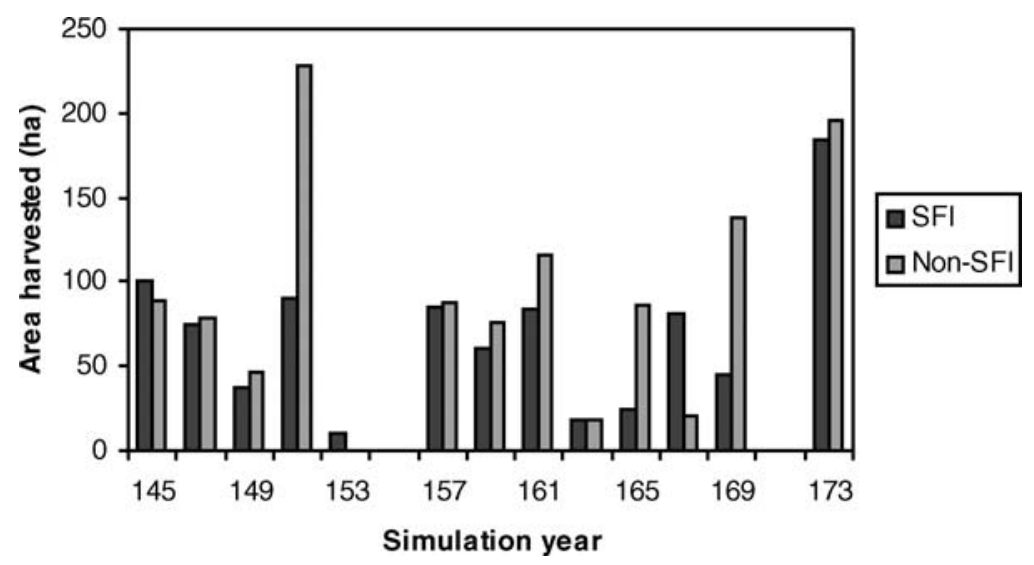

Figure 6. Area harvested in the study area during the simulation period for SFI and non-SFI scenarios.

\section{Acknowledgements}

We thank Temple-Inland Forest Products Corporation, Texas, USA, Instituto Politécnico de Bragança, Portugal, Luso-American Development Foundation (FLAD), and the PRODEP III program of the Portuguese government by supporting 
this research. We also thank two anonymous reviewers for suggestions on the manuscript.

\section{References}

AF\&PA, 2003, 'Sustainable Forestry Initiative: A Good Sign Somebody Cares', Eighth Annual Progress Report, AF\&PA, Washington D.C.

Azevedo, J. C., Wu, X. B., Messina, M. G., and Fisher, R. F., 2003, 'Development of a methodology for the assessment of sustainability in intensively managed forested landscapes in East Texas', Submitted.

Bagnold, R. A., 1977, 'Bed-load transport by natural rivers', Water Resour. Res. 13(2), 303-312.

Baldwin, Jr., V. C., Peterson, K. D., Clark, III, A., Ferguson, R. B., Strub, M. R. and Bower, D. R., 2000, 'The effects of spacing and thinning on stand and tree characteristics of 38 year-old Loblolly Pine', For. Ecol. Manage. 137(1/3), 91-102.

Beasley, R. S. and Granillo, A. B., 1983, 'Sediment Losses from Forest Practices in the Gulf Coastal Plain of Arkansas', in E. P. Jones, Jr. (ed), Proceedings of the Second Biennial Southern Silvicultural Research Station Conference, USDA for. Serv. Gen. Tech. Rep. SRS-47, pp. 461-467.

Beasley, R. S. and Granillo, A. B., 1988, 'Sediment and water yields from managed forests on flat Coastal Plain soils', Water Resour. Bull. 24(2), 361-366.

Beasley, R.S., Granillo, A.B. and Zilmer, V., 1986, 'Sediment losses from forest management: mechanical vs. chemical site preparation after clearcutting', J. Environ. Qual. 15, 413-416.

Blackburn, W. H., Wood, J. C. and DeHaven, M. G.,1986, 'Stormflow and sediment losses from site-prepared forestland in East Texas', Water Resour. Res. 22, 776-784.

Blackburn, W. H., Knight, R. W., Wood, J. C. and Pearson, H. A., 1990, 'Stormflow and sediment loss from intensively managed forest watersheds in East Texas', Water Resour. Bull. 26(3), 465-477.

Carling, P. A., Irvine, B. J., Hill, A. and Wood, M., 2001, 'Reducing sediment inputs to Scottish streams: A review of the efficacy of soil conservation practices in upland forestry', Sci. Total. Environ. 265(1-3), 209-227.

Chang, M., Roth, II, F. A. and Hunt, Jr., E. V., 1982, 'Sediment production under various forestsite conditions', in D. E. Walling (ed), Recent Developments in the Explanation and Prediction of Erosion and Sediment Yield, Proceedings of the Exeter Symposium, Publcation No. 137, International Association of Hydrological Sciences, Wallingford, England, pp.13-22.

Di Luzio, M, Srinivasan, R., Arnold, J. G. and Neitsch, S. L., 2002, 'ArcView Interface for Swat2000 - User's Guide', Report TR-93, Texas Water Resources Institute, College Station, TX.

Grace, J. M., III, 2002, 'Effectiveness of vegetation in erosion control from forest road sideslopes', Transactions of the ASAE 45(3), 681-685.

Gresham, C. A. and Williams, T. M., 2002, 'Biomass, nitrogen and phosphorus accumulation in 4-year-old intensively managed loblolly pine and sweetgum plantations', in W. Kenneth (ed), Proceedings of the Eleventh Biennial Southern Silvicultural Research Conference, US For. Serv. Gen. Tech. Rep. SRS-48, pp. 3-6.

Gustafson, E. J. and Crow, T. R., 1999, 'HARVEST: Linking timber harvesting strategies to landscape patterns', in D. J. Mladenoff and W. L. Baker (eds), Spatial Modeling of Forest Landscape Change: Approaches and Applications, Cambridge University Press, New York, pp. 309-332.

Hargreaves, G. H. and Samani, Z. A., 1985, 'Reference crop evapotranspiration from temperature', Appl. Engr. Agric. 1, 96-99.

Hebert, M. T. and Jack, S. B., 1997, 'Leaf area index and site water balance of loblolly pine (Pinus taeda L.) across a precipitation gradient in East Texas', Forest Ecol. Manage. 105, 273-282.

Ice, G. G., Stuart, G. W., Waide, J. B., Irland, L. C. and Ellefson, P. V., 1997, '25 years of the Clean Water Act: How clean are forest practices?,' J. Forestry 95(7), 9-13. 
Marion, D. A. and Ursic, S. J., 1993, 'Sediment production in forests of the Coastal Plain, Piedmont and Interior Highlands', in Terrene Institute (ed), Technical Workshop on Sediments; Proceedings of the EPA/Forest Service Workshop, Terrene Institute, Corvallis, OR, pp. 19-27.

McClurkin, D. C., Duffy, P. D. and Nelson, N. S., 1987, 'Changes in forest floor and water-quality following thinning and clearcutting of 20-year-old pine', J. Environ. Qual. 16(3), 237-241.

Ministerial Conference on the Protection of Forests in Europe, 2003, 'Background information for improved pan-european indicators for sustainable forest management', Vienna, Austria. [http://www.lu-vienna.at/livingforestsummit/ secure/k-tools/phplib/MedienDatenbankView .inc.php?id=123].

Montréal Process Working Group, 1999, 'Criteria and indicators for the conservation and sustainable management of temperate and boreal forests', The Montréal Process, 2nd (edn), December, 1999. [http://www.mpci.org/rep-pub/1999/ci_e.html].

Pope, P. E. and Graney, D. L., 1979, 'Family differences influence the aboveground biomass of loblolly pine plantations', USDA For. Serv. Research Paper SO-155.

Saleh, A., Williams, J. R., Wood, J. C., Hauck, L. and Blackburn, W. H., 2002, Application of APEX for forestry, in Proceedings of the 2002 Conference on Total Maximum Daily Load (TDML): Environmental Regulations, American Society of Agricultural Engineers, St. Joseph, MI, pp. 595605.

Texas Forest Service, 2000, 'Forestry best management practices', Texas Forestry Association.

Ursic, S. J., 1991a, 'Hydrologic effects of two methods of harvesting mature southern pine', Water Resour. Bull. 27(2), 303-315.

Ursic, S. J., 1991b, 'Hydrologic effects of clearcutting and stripcutting loblolly-pine in the coastalplain', Water Resour. Bull. 27(6), 925-937.

Ursic, S. J., 1986, 'Sediment and forestry practices in the South', in Proceedings of the Fourth Federal Interagency Sedimentation Conference, Subcommittee on Sedimentation of the Interagency Advisory Committee on Water Data, Las Vegas, Nevada, pp. 2:28-37.

U.S. Department of Agriculture, Soil Conservation Service, 1972, National Engineering Handbook, Hydrology Section 4, Chapters 4-10.

Williams, J. R., 1990, 'The erosion-productivity impact calculator (EPIC) model: A case history,' Phil. Trans. R. Soc. Lond. B 329, 421-428.

Williams, J. R., 1995, 'The EPIC model, in V. P. Singh (ed), Computer Models of Watershed Hydrology, Water Resources Publications, Highlands Ranch, CO, pp. 909-1000.

Williams, J. R., Jones, C. A. and Dyke, P. T., 1984, 'A modeling approach to determining the relationship between erosion and soil productivity', Transactions of the ASAE 27, 129-144.

Williams, J. R., Arnold, J. G. and Srinivasan, R., 2000, 'The APEX model. BRC', Report No. 00-06, Texas Agricultural Experiment Station, Blackland Research Center, Temple, TX.

Williams, J. R., Arnold, J. G., Srinivasan, R. and Ramanarayanan, T. S., 1998, 'APEX: A new tool for predicting the effects of climate changes and CO2 changes on erosion and water quality', in J. Boardman and D. Favis-Mortlock (eds), Modeling Soil Erosion by Water, Springer-Verlag, NATO-ASI Global Change Series 1-55, Heidelberg, pp. 441-449.

Wynn, T. M., Mostaghimi, S., Frazee, J. W., McClellan, P. W., Shaffer R. M. and Aust, W. M., 2000, 'Effects of forest harvesting best management practices on surface water quality in the Virginia coastal plain', Transactions of the ASAE 43(4), 927-936.

Yoho, N. S., 1980, 'Forest management and sediment production in the South-A review', South. J. Appl. Forestry. 4, 27-36. 